\title{
Urea-N recycling in lactating dairy cows fed diets with 2 different levels of dietary crude protein and starch with or without monensin
}

\author{
E. B. Recktenwald, D. A. Ross, S. W. Fessenden, C. J. Wall, and M. E. Van Amburgh' \\ Department of Animal Science, Cornell University, Ithaca, NY 14853
}

\section{ABSTRACT}

Rumensin (monensin; Elanco Animal Health, Greenfield, IN) has been shown to reduce ammonia production and microbial populations in vitro; thus, it would be assumed to reduce ruminal ammonia production and subsequent urea production and consequently affect urea recycling. The objective of this experiment was to determine the effects of 2 levels of dietary crude protein (CP) and 2 levels of starch, with and without Rumensin on urea- $\mathrm{N}$ recycling in lactating dairy cattle. Twelve lactating Holstein dairy cows $(107 \pm 21 \mathrm{~d}$ in milk, 647 $\mathrm{kg} \pm 37 \mathrm{~kg}$ of body weight) were fed diets characterized as having high $(16.7 \%)$ or low $(15.3 \%) \mathrm{CP}$ with or without Rumensin, while dietary starch levels (23 vs. 29\%) were varied between 2 feeding periods with at least $7 \mathrm{~d}$ of adaptation between measurements. Cows assigned to high or low protein and to Rumensin or no Rumensin remained on those treatments to avoid carryover effects. The diets consisted of approximately $40 \%$ corn silage, $20 \%$ alfalfa hay, and $40 \%$ concentrate mix specific to the treatment diets, with $0.5 \mathrm{~kg}$ of wheat straw added to the high starch diets to enhance effective fiber intake. The diets were formulated using Cornell Net Carbohydrate and Protein System (version 6.1), and the lowprotein diets were formulated to be deficient for rumen ammonia to create conditions that should enhance the demand for urea recycling. The high-protein diets were formulated to be positive for both rumen ammonia and metabolizable protein. Rumen fluid, urine, feces, and milk samples were collected before and after a 72-h continuous jugular infusion of ${ }^{15} \mathrm{~N}^{15} \mathrm{~N}$-urea. Total urine and feces were collected during the urea infusions for $\mathrm{N}$ balance measurements. Milk yield and dry matter intake were improved in cows fed the higher level of dietary $\mathrm{CP}$ and by Rumensin. Ruminal ammonia and milk and plasma urea nitrogen concentrations corresponded to dietary CP concentration. As has been shown in vitro, Rumensin reduced rumen ammonia concentration by approximately $23 \%$ but did not affect urea entry rate

Received June 20, 2013.

Accepted November 2, 2013.

${ }^{1}$ Corresponding author: mev1@cornell.edu or gastrointestinal entry rate. Urea entry rate averaged approximately $57 \%$ of total $\mathrm{N}$ intake for cattle with and without Rumensin, and gastrointestinal rate was similar at 43 and $42 \%$ of $\mathrm{N}$ intake for cattle fed and not fed Rumensin, respectively. The cattle fed the highprotein diet had a $25 \%$ increase in urea entry rate and no effect of starch level was observed for any recycling parameters. Contrary to our hypothesis, Rumensin did not alter urea production and recycling.

Key words: urea recycling, Rumensin, nitrogen efficiency

\section{INTRODUCTION}

With the current environmental concerns regarding nitrogen $(\mathrm{N})$ emissions and the potential effect on the environment (Jonker et al., 2002), improving $\mathrm{N}$ efficiency in dairy cattle is of interest (Colmenero and Broderick, 2006; Higgs et al., 2012). To enhance N efficiency, a better understanding of the amount and utilization of urea $\mathrm{N}$ recycling in dairy cows is important to improve the $\mathrm{N}$ efficiency of dairy cattle and thus reduce the environmental impact of dairy farms. Various studies have examined the effect of $\mathrm{N}$ intake, different forms of energy supplementation, and exogenous urea infusions on the quantity of urea recycled to the gastrointestinal tract (Ouellet et al., 2004; Valkeners et al., 2007).

Crude protein levels of approximately $14 \%$ appear to approach ruminal $\mathrm{N}$ deficiency in high-producing dairy cattle, with animals on these diets beginning to display impaired production and the resulting lower $\mathrm{N}$ efficiencies (Schwab et al., 2005; Recktenwald, 2007). An approach to improve $\mathrm{N}$ efficiency is to reduce urinary urea- $\mathrm{N}$ clearance by the kidney and stimulate urea-N re-entry to the rumen, to provide $\mathrm{N}$ for microbial maintenance and growth while creating ruminal conditions that enhance microbial uptake of the recycled urea N. Urea entry to the rumen has been hypothesized to be regulated via a nitrogen concentration gradient across the rumen wall in combination with alterations in the permeability of the epithelial boundary (Kennedy and Milligan, 1978; Abdoun et al., 2006) through changes in urea transporter activity (Marini et al., 2005). Nitrogen intake has been demonstrated to affect ruminal urea- 
$\mathrm{N}$ entry, with higher $\mathrm{N}$ intakes typically resulting in higher N recycling (Valkeners et al., 2007). However, the effect of $\mathrm{N}$ intake is not always consistent or linear (Reynolds and Kristensen, 2008). Further, urea-N can re-enter the rumen via saliva production during the process of chewing and rumination and can be a significant contributor to the urea-N pool (Maltby et al., 2005).

Dietary carbohydrate has been observed to stimulate urea-N entry to the rumen, most likely through effects on microbial growth and the subsequent depletion of ruminal N supply (Kennedy et al., 1981; Al-Dehneh et al., 1997). Carbohydrate fermentation might also have a secondary effect by altering the permeability of the epithelial boundary through VFA and $\mathrm{CO}_{2}$ production (Abdoun et al., 2006). Both of these metabolic byproducts have been demonstrated to stimulate urea-N entry and might aid in controlling $\mathrm{N}$ supply to the rumen to support the bacteria under conditions of high fermentable carbohydrate availability (Thorlacius et al., 1971; Rémond et al., 1993).

In vivo and in vitro data suggest that the ionophore Rumensin (Elanco Animal Health, Greenfield, IN) decreases feed proteolysis and rumen ammonia concentrations by reducing the obligate AA fermenting bacteria (Russell and Rychlik, 2001; Eschenlauer et al., 2002). Rumensin inhibits the metabolism and growth of mainly gram-positive bacterial species in addition to several strains of protozoa (Sylvester et al., 2009). In particular, its ability to slow the activity of certain hyper-ammonia-producing bacteria allows it to aid in conservation of feed AA and peptides, potentially enhancing feed AA flow out of the rumen (Choi et al., 2002; Eschenlauer et al., 2002). With that mechanism, more feed AA should escape rumen fermentation and increase the delivery of feed AA to the animal and also potentially increase the demand for recycled urea- $\mathrm{N}$ in the rumen because of lower ruminal ammonia concentrations. Russell and Strobel (1989) provided a general model of ionophore function in the rumen, which suggested that reduced ammonia production and altered fermentation should result in reduced urea formation and subsequently altered urea recycling and or urea excretion. An indication that this model might translate to in vivo data was first described by Poos et al. (1979). However, the level to which this occurs in vivo in lactating cattle is unclear (Ruiz et al., 2001; Broderick, 2004).

Nitrogen intake, starch intake, and Rumensin all have potential effects on urea-N production and utilization along with potential changes in $\mathrm{N}$ efficiency. The objective of this study was to examine how those components work in conjunction to affect the animal's $\mathrm{N}$ metabolism, specifically ruminal $\mathrm{N}$ transamination through urea production and metabolic fate. The hypotheses were that urea production would parallel $\mathrm{N}$ intake and be reduced by the addition of Rumensin because of a decrease in rumen ammonia production. Further, gastrointestinal urea-N entry would be enhanced by greater dietary starch intake, and the addition of Rumensin would increase the need for recycled urea$\mathrm{N}$ due to lower ammonia production combined with greater microbial demand for ammonia $\mathrm{N}$.

\section{MATERIALS AND METHODS}

\section{Experimental Design}

Twelve multiparous, lactating Holstein dairy cows $[107 \mathrm{DIM} \pm 21 \mathrm{~d}, 647 \mathrm{~kg}$ of $\mathrm{BW} \pm 37 \mathrm{~kg}, 3.0 \pm 0.3$ BCS (1-5 scale)] fitted with rumen fistulas were fed 1 of 8 different diets in a crossover design. Fistulas were established in the cattle approximately 2 mo before study. Animals were kept at the Cornell Teaching and Research Facility (Harford, NY), and the Cornell University Institutional Animal Care and Use Committee approved all animal-related procedures. The diets were formulated to contain either 16.5 or $15.3 \% \mathrm{CP}$ and 29 or $23 \%$ starch, resulting in 4 compositionally different diets. In addition, Rumensin was included in the diets for 6 of the cows, and the other 6 received no Rumensin. Once assigned to Rumensin, the cows remained on that treatment to avoid long-term carryover effects due to potential long-term changes in rumen microbial population caused by the effects of the ionophore. Thus, with ionophore inclusion, 8 separate diets served as treatments for this experiment (Tables 1 and 2).

The cows were housed in individual tiestalls and fed a TMR once daily at approximately $0900 \mathrm{~h}$ at a $10 \%$ refusal rate. The TMR consisted of approximately $40 \%$ corn silage, $20 \%$ alfalfa hay, and $40 \%$ concentrate mix specific to dietary objectives (Tables 2 and 3). Wheat straw $(0.5 \mathrm{~kg} / \mathrm{d})$ was included in the high-starch diets to enhance physically effective NDF and potentially reduce passage rate. Diets were formulated for $40 \mathrm{~kg}$ of ME- and MP-allowable milk using CNCPS v6.1 (Cornell University, Ithaca, NY; Fox et al., 2004; Tylutki et al., 2008) and were based on previous work that evaluated $\mathrm{N}$ efficiency in lactating cattle (Recktenwald, 2007).

The high-protein diets were formulated to be adequate for both MP and ruminal $\mathrm{N}$ balance, and the low-protein diets were formulated to be slightly deficient in ruminal $\mathrm{N}$ balance but to contain adequate MP. This was done to create a range in potential rumen fermentation conditions and ruminal $\mathrm{N}$ balance to evaluate ureagenesis and urea recycling. Starch levels were increased in the high-starch diets through the ad- 
Table 1. The experimental design of the study ${ }^{1}$

\begin{tabular}{|c|c|c|c|c|c|c|c|}
\hline \multicolumn{4}{|c|}{ High protein $(\mathrm{n}=6)$} & \multicolumn{4}{|c|}{ Low protein $(\mathrm{n}=6)$} \\
\hline $\begin{array}{l}\text { High starch } \\
(\mathrm{n}=3)\end{array}$ & $\begin{array}{l}\text { Low starch } \\
\quad(\mathrm{n}=3)\end{array}$ & $\begin{array}{l}\text { High starch } \\
\quad(\mathrm{n}=3)\end{array}$ & $\begin{array}{l}\text { Low starch } \\
\quad(\mathrm{n}=3)\end{array}$ & $\begin{array}{l}\text { High starch } \\
\quad(\mathrm{n}=3)\end{array}$ & $\begin{array}{l}\text { Low starch } \\
\quad(\mathrm{n}=3)\end{array}$ & $\begin{array}{l}\text { High starch } \\
\quad(\mathrm{n}=3)\end{array}$ & $\begin{array}{l}\text { Low starch } \\
\quad(\mathrm{n}=2)\end{array}$ \\
\hline
\end{tabular}

${ }^{1}$ Cows assigned to high or low protein and to Rumensin (Elanco Animal Health, Greenfield, IN) or no Rumensin remained on those treatments (fixed), but crossed on starch throughout the treatment period. Thus, for each starch treatment, 3 observations were made except for the lowprotein, low-starch treatment without Rumensin, where 1 cow had unusually low ${ }^{15} \mathrm{~N}$ enrichment levels.

dition of steam-flaked corn, which should provide more fermentable starch for microbial growth and therefore increase ruminal $\mathrm{N}$ requirements for microbial growth and potentially enhance urea-N recycling (Table 2 ).

Rumensin was included in the TMR of 6 cows at a formulated rate of $400 \mathrm{mg} / \mathrm{cow}$ per day. To prevent any carryover effects of Rumensin, once a cow was assigned to the ionophore treatment, they remained on it for the duration of the study. Cows were also maintained on either high- or low-protein diets to avoid potential long-term adjustments in ruminal and whole-body $\mathrm{N}$ status. Therefore, cows participated in 2 treatments each, in which they were switched between the 2 dietary starch levels. All cows were given bST per label (Posilac, Elanco Animal Health) to help maintain milk yield during the study period, and bST administration

Table 2. Treatment diets, ingredients, and chemical composition (\%, DM basis)

\begin{tabular}{|c|c|c|c|c|}
\hline Item & $\begin{array}{l}\text { High protein, } \\
\text { high starch }\end{array}$ & $\begin{array}{l}\text { High protein, } \\
\text { low starch }\end{array}$ & $\begin{array}{l}\text { Low protein, } \\
\text { high starch }\end{array}$ & $\begin{array}{c}\text { Low protein, } \\
\text { low starch }\end{array}$ \\
\hline Corn silage & 37.71 & 38.10 & 36.77 & 37.99 \\
\hline Alfalfa hay & 18.69 & 19.10 & 18.43 & 19.42 \\
\hline Wheat straw & 1.90 & - & 1.89 & - \\
\hline Steam-flaked corn & 11.26 & 5.82 & 11.50 & 5.66 \\
\hline Cornmeal & 10.92 & 5.78 & 11.37 & 5.49 \\
\hline Soybean meal & 7.40 & 6.51 & 3.35 & 1.87 \\
\hline Citrus pulp & 4.00 & 11.30 & 3.60 & 7.92 \\
\hline Soy hulls & - & 4.02 & 1.72 & 7.45 \\
\hline Amino Plus ${ }^{1}$ & 3.79 & 4.17 & 5.45 & 6.73 \\
\hline Dextrose & 0.83 & - & 0.90 & - \\
\hline Cargill fat & 0.56 & 0.86 & 0.60 & 0.85 \\
\hline Blood meal & 0.42 & 0.41 & 0.43 & 0.37 \\
\hline Sodium bicarbonate & 0.42 & 0.43 & 0.43 & 0.43 \\
\hline Salt & 0.40 & 0.39 & 0.39 & 0.40 \\
\hline Limestone & 0.36 & 0.00 & 0.46 & 0.31 \\
\hline Monocalcium sulfate & 0.36 & 0.33 & 0.33 & 0.27 \\
\hline Calcium sulfate & 0.30 & 0.32 & 0.18 & 0.34 \\
\hline Urea & 0.23 & 0.21 & - & - \\
\hline Magnesium oxide & 0.20 & 0.18 & 0.16 & 0.16 \\
\hline Wheat middlings & 0.08 & 1.92 & 1.76 & 4.17 \\
\hline Selenium $^{2}$ & 0.05 & 0.04 & 0.04 & 0.04 \\
\hline Alimet $^{3}$ & 0.03 & 0.03 & 0.03 & 0.03 \\
\hline 1100 Dairy $\mathrm{TM}^{4}$ & 0.03 & 0.03 & 0.03 & 0.03 \\
\hline Dairy ADE-AL/MA ${ }^{5}$ & 0.03 & 0.02 & 0.02 & 0.03 \\
\hline Smartamine $\mathrm{M}^{6}$ & 0.017 & 0.017 & 0.017 & 0.017 \\
\hline Zinc sulfate & 0.004 & 0.004 & 0.004 & 0.004 \\
\hline Manganese sulfate & 0.004 & 0.004 & 0.004 & 0.004 \\
\hline Dynamate/KMS $050^{7}$ & - & - & 0.12 & - \\
\hline
\end{tabular}

${ }^{1}$ Amino Plus (Ag Processing Inc., Hastings, NE) heat-treated soybean meal product, $51.5 \% \mathrm{CP}, 1.30 \%$ fat, $2.18 \mathrm{Mcal}$ of $\mathrm{NE}_{\mathrm{L}} / \mathrm{kg}$.

${ }^{2}$ Cargill selenium (calcium 31\% of DM, selenium $603 \mathrm{mg} / \mathrm{kg}$; Cargill Inc., Minneapolis, MN).

${ }^{3}$ Alimet (DL-methionine hydroxy analog $88 \%$; Novus Inc., St. Louis, MO).

${ }^{4}$ Cargill 1100 Dairy trace mineral (calcium $0.022 \%$, sulfur $18.816 \%$, copper $30,317 \mathrm{mg} / \mathrm{kg}$, manganese 136,466 $\mathrm{mg} / \mathrm{kg}$, cobalt 3,393 mg/kg, iodine $3,040 \mathrm{mg} / \mathrm{kg}$, zinc 153,916 mg/kg; Cargill Inc.)

${ }^{5}$ Cargill Dairy ADE-AL/MA (vitamin A, 30,464 IU/g, vitamin D, 5,862 IU/g, vitamin E, 93,784 IU/kg; Cargill Inc.).

${ }^{6}$ Smartamine M (Adisseo, Alpharetta, GA).

${ }^{7}$ Dynamate/KMS (sulfur 24\%, magnesium 12\%, and potassium 19\%; Mosaic Co., Plymouth, MN). 
Table 3. Measured chemical composition (\% of DM unless otherwise noted) of the forages fed

\begin{tabular}{lccc}
\hline Item & Corn silage & Alfalfa hay & Wheat straw \\
\hline DM, \% & 31.9 & 88.2 & 88.9 \\
CP & 8.49 & 19.6 & 4.89 \\
Soluble CP, \% of CP & 67.7 & 40.1 & 41.8 \\
NDF & 42.9 & 42.4 & 79.8 \\
ADF & 23.5 & 32.3 & 52.7 \\
Lignin, \% of NDF & 6.59 & 14.7 & 12.2 \\
Starch & 31.9 & 1.48 & 1.57 \\
Sugar & 1.39 & 6.71 & 2.01 \\
Crude fat & 3.40 & 1.54 & 1.45 \\
Neutral detergent insoluble CP, \% of CP & 10.7 & 18.8 & 31.5 \\
Acid detergent insoluble CP, \% of CP & 3.77 & 4.31 & 16.3 \\
\hline
\end{tabular}

was synchronized such that all cows were at the same stage of the bST cycle during stable isotope infusions. Before and after treatment, the BW and BCS of the cattle were measured and BCS was assessed on a 1 to 5 scale (Wildman et al., 1982).

The cattle were given an initial adaptation period of approximately $21 \mathrm{~d}$ to the fixed components of the diet and were given at least $7 \mathrm{~d}$ of adaptation to the starch diet before ${ }^{15} \mathrm{~N}^{15} \mathrm{~N}$ urea infusions and related measurements were taken, with the average starch adaptation period being $17 \mathrm{~d}$. Each period change was done on a cow-by-cow basis and not by treatment. Cows were moved to metabolism stalls for the infusion and collection periods. Cows were milked 3 times per day at 0700 , 1500 , and $2300 \mathrm{~h}$ in their stalls with a portable milking machine, and milk was weighed via a calibrated and certified digital scale. Each milking was sub-sampled in the milk pail and preserved with 2-bromo-2-nitropropane-1,3, diol for milk component analysis (Dairy One, Ithaca, NY). Feces, urine, plasma, and rumen fluid samples were taken before jugular ${ }^{15} \mathrm{~N}^{15} \mathrm{~N}$-urea infusions to establish ${ }^{15} \mathrm{~N}$ background values. Before the infusion period, feces were collected by either voluntary elimination or rectal palpation into 1-gallon plastic bags and then frozen. Before ${ }^{15} \mathrm{~N}^{15} \mathrm{~N}$-urea infusions, urine was collected by manual agitation of the lower vulva, $50 \%$ $\mathrm{H}_{2} \mathrm{SO}_{4}$ (vol/vol) was added until $\mathrm{pH}<2$, and then samples were frozen in conical vials. Blood was collected into Vacutainers containing heparin (Becton Dickinson, Rutherford, NJ) via the coccygeal vessels, placed on ice, and centrifuged at $1,500 \times g$ for 15 min to obtain plasma. Ruminal contents were collected for ammonia $\left(\mathrm{NH}_{3}-\mathrm{N}\right)$ measurements by sampling at approximately 4 to 5 locations throughout the rumen. The rumen samples were squeezed through 4 layers of cheesecloth, and the extracted fluid immediately acidified with 1 $\mathrm{mL}$ of $50 \%$ ( vol/vol) $\mathrm{H}_{2} \mathrm{SO}_{4}$ in $40 \mathrm{~mL}$ of rumen fluid and frozen in conical vials for $\mathrm{NH}_{3}-\mathrm{N}$ analysis.

For the infusion period, animals were prepared with indwelling jugular vein catheters (Micro-Renathane polyvinyl; Braintree Scientific Inc., Braintree, MA) at least $1 \mathrm{~d}$ before the start of a continuous infusion of ${ }^{15} \mathrm{~N}^{15} \mathrm{~N}$-urea (98\% purity, Cambridge Isotope Laboratories Inc., Andover, MA) in sterile saline (9 g of NaCl/L) at $0.0278 \mathrm{~g}$ of urea/h. The labeled urea solution was prepared as needed and refrigerated at $4^{\circ} \mathrm{C}$ if not used immediately. The urea solution was infused using a MasterFlex Pump 4S (Cole-Parmer, Vernon Hills, IL) with an EasyLoad head and L/S 14 tubing and set for 0.22 to $0.28 \mathrm{~mL} / \mathrm{min}$ infusion rate.

Feces, urine, plasma, and rumen fluid samples were taken at least $72 \mathrm{~h}$ after initiating the infusion using the same procedures as those used for background sampling, except that urine was collected via urinary catheters maintained for the purpose of total urine collection and feces were collected from trays mounted below the stalls. The infusion period was established based on the data of Lobley et al. (2000) and Marini and Van Amburgh (2003), indicating that a plateau in ${ }^{15} \mathrm{~N}^{15} \mathrm{~N}$ urea enrichment within the animal would be achieved by that time. The urinary catheters were placed in the cows $24 \mathrm{~h}$ before the beginning of the infusion. The catheters were 8-gauge Foley catheters (22 French, 75-mL; C. R. Bard Inc., Covington, GA) and were connected to sealed plastic bags that were emptied 3 times a day into a carboy that contained adequate $\mathrm{H}_{2} \mathrm{SO}_{4}$ to reduce the $\mathrm{pH}$ to $<2$. For total collection, urine was composited every $24 \mathrm{~h}$; the composite represented $10 \%$ of the total excretion weight for the period and was stored at $4^{\circ} \mathrm{C}$ until analyzed. Feces were subsampled on a daily basis and then combined over the collection period.

The analysis for fecal and plasma ${ }^{15} \mathrm{~N}$ enrichment were determined on freeze-dried samples with a NC2500 elemental analyzer (Carlo Erba, Milan, Italy) interfaced to a Delta Plus isotope ratio mass spectrometer (ThermoFinnigan, Bremen, Germany). Urinary urea was isolated via a cation exchange resin (AG 50W-X8, 100-200 mesh hydrogen form, Bio-Rad Laboratories, Hercules, CA), diluted to $6 \mathrm{mmol} / \mathrm{L}$, and reacted with lithium hypobromite under vacuum (Marini and Attene-Ramos, 2006). The resulting $\mathrm{N}_{2}$ gas was ana- 
lyzed with a PDZ Europa Geo 20/20 isotope ratio mass spectrometer (EA-IRMS; Sercon Ltd., Cheshire, UK) attached to the ANCA-trace gas/liquid system. The model of Lobley et al. (2000) was used to calculate urea kinetics.

Total N content of the wet feces was analyzed with a Kjeltec 2300 analyzer (Foss Analytical, Hillerød, Denmark). Ruminal ammonia and plasma urea concentrations were measured using the procedure of Chaney and Marbach (1962).

Feed ingredients, TMR, and orts were sampled daily during both the adaptation and infusion periods, dried in a forced-air oven at $60^{\circ} \mathrm{C}$ for $24 \mathrm{~h}$, and then subsampled for weekly determination of the chemical composition. The subsamples were ground through a Wiley mill (A. H. Thomas, Philadelphia, PA) with a 1-mm screen and another subsample was sent to Dairy One (Ithaca, NY) for wet chemistry analyses. Diet ingredients were analyzed for chemical components necessary to meet the inputs necessary for the CNCPS (wet chemistry package 315, Dairy One Forage Laboratory). The TMR and orts were analyzed for DM, CP, soluble CP, NDF, ADF, lignin, starch, sugar, crude fat, neutral detergent insoluble CP and acid detergent insoluble CP (Ration Balancer Plus package, Dairy One Forage Laboratory).

\section{Statistical Design and Analysis}

Data were analyzed with the PROC MIXED procedure of SAS (SAS Institute Inc., Cary, NC) with the model

$$
\begin{gathered}
\mathrm{Y}_{\mathrm{ijklm}}=\mu+\mathrm{T}_{\mathrm{i}}+\mathrm{P}_{\mathrm{j}}+\mathrm{S}_{\mathrm{k}}+\mathrm{R}_{\mathrm{l}}+\mathrm{PS}_{\mathrm{jk}} \\
+\mathrm{PR}_{\mathrm{jl}}+\mathrm{SR}_{\mathrm{kl}}+\mathrm{C}_{\mathrm{m}}+\mathrm{P}_{\mathrm{n}}+\mathrm{E}_{\mathrm{ijklm}},
\end{gathered}
$$

where $Y_{\mathrm{ijklm}}=$ dependent variable, $\mu=$ overall mean, $\mathrm{T}_{\mathrm{i}}=$ effect of dietary treatment $\mathrm{i}, \mathrm{P}_{\mathrm{j}}=$ effect of dietary $\mathrm{CP}$ level $\mathrm{j}, \mathrm{S}_{\mathrm{k}}=$ effect of dietary starch level $\mathrm{k}, \mathrm{R}_{\mathrm{l}}=$ effect of feed additive 1 (Rumensin vs. no additive), $\mathrm{PS}_{\mathrm{jk}}=$ interaction of dietary CP level $\mathrm{j}$ and starch level $\mathrm{k}, \mathrm{PR}_{\mathrm{jl}}=$ interaction of dietary $\mathrm{CP}$ level $\mathrm{j}$ and feed additive $1, \mathrm{SR}_{\mathrm{kl}}=$ interaction of dietary starch level $\mathrm{k}$ and feed additive $1, \mathrm{C}_{\mathrm{m}}=$ effect of cow $\mathrm{m}, \mathrm{P}_{\mathrm{n}}=$ effect of experimental period $\mathrm{n}$, and $\mathrm{E}_{\mathrm{ijklm}}=$ residual error. All terms were considered fixed except for $\mathrm{C}_{\mathrm{m}}$ and $\mathrm{E}_{\mathrm{ijk} k \mathrm{~m}}$, which were considered random.

Repeated measures were used for analysis of daily milk yield, milk components (fat \%, protein \%, lactose \%, and MUN) and component yield, DMI, and N intake. Autoregressive order 1 was used as the covariance structure with repeated measures. The LSMEANS option was used to determine treatment, factor, and factor interaction means, and these were adjusted using the PDIFF option. Type 3 tests of the fixed effects were used to determine significance, which was declared at $P$ $<0.05$ and a statistical trend was declared at $P<0.10$.

\section{RESULTS AND DISCUSSION}

\section{Production Outcomes}

All cattle finished the allocated treatments; however, one cow receiving the low-protein, low-starch diet without Rumensin had unusually low ${ }^{15} \mathrm{~N}$ enrichment values (less than $50 \%$ of expected) after analysis of the infusion period data and was not included in the analysis of urea recycling for one period. The treatment means for BW of cattle ranged from 584 to $688( \pm 37.3) \mathrm{kg}$ and BCS ranged from 2.8 to $3.1( \pm 0.29)$ with no significant differences among treatments for either BW or BCS. Overall, the cattle were approximately 107 DIM $( \pm 21$ d) during the first ${ }^{15} \mathrm{~N}^{15} \mathrm{~N}$-urea infusion and $117 \mathrm{DIM}$ $( \pm 21 \mathrm{~d})$ for the second infusion. No significant differences were observed among treatment means for DIM at initiation of infusions.

Actual dietary CP concentrations were close to formulated values for both the high- and low-protein diets (Tables 2 and 4). Dietary starch concentrations were also similar to formulated values. Alfalfa hay and corn silage were relatively consistent throughout the duration of the study, varying in $\mathrm{CP}$ concentration from 18.3 to $21.2 \%$ and from 8.3 to $8.9 \% \mathrm{CP}$, respectively, and this consistency resulted in little variance among treatment diets. Dry matter intake was significantly greater $(P<0.01)$ for cows consuming the high-protein diets (averaging 25.7 vs. $22.9 \mathrm{~kg}$ of $\mathrm{DMI} / \mathrm{d}$ ), and we observed a trend $(P=0.06)$ for DMI to be higher for Rumensin-fed cattle (24.9 vs. $24.1 \mathrm{~kg}$ of DMI/d; Table $5)$. The DMI observed on this study were similar to studies feeding high levels of corn silage in combination with alfalfa silage (Wattiaux and Karg, 2004) and lower protein diets (Law et al., 2009). Previous work has demonstrated DMI inhibition with low dietary $\mathrm{CP}$ concentrations, due mainly to effects of ruminal $\mathrm{N}$ deficiency on microbial fermentation (Ruiz et al., 2002; Broderick, 2003). In this study, because the low-protein diets were formulated to be near zero in rumen $\mathrm{N}$ balance, the observation of lower DMI indicates that the formulation objectives were most likely achieved.

Milk yield was significantly greater for cattle fed high-protein and high-starch diets (by 7.7 and 3.4\%, respectively) and were consistent with the data of Law et al. (2009), where cattle fed diets ranging from 11.4 to $17.3 \% \mathrm{CP}$ yielded between 25.4 and $35.4 \mathrm{~kg}$ of milk per day. Milk fat percentage and milk fat yield ranged from 3.58 to $4.01 \%$ (Table 5), were not different among treatments, and were similar to or higher than those 
Table 4. Analyzed chemical composition (\% of DM unless otherwise noted) of the treatment diets

\begin{tabular}{lcccc}
\hline Item & $\begin{array}{c}\text { High protein, } \\
\text { high starch }\end{array}$ & $\begin{array}{c}\text { High protein, } \\
\text { low starch }\end{array}$ & $\begin{array}{c}\text { Low protein, } \\
\text { high starch }\end{array}$ & $\begin{array}{c}\text { Low protein, } \\
\text { low starch }\end{array}$ \\
\hline $\mathrm{DM}, \%$ & 53.0 & 55.0 & 55.9 & 55.6 \\
$\mathrm{CP}$ & 16.7 & 16.6 & 15.1 & 15.2 \\
Soluble CP, \% of CP & 35.4 & 36.1 & 36.2 & 36.7 \\
NDF & 29.8 & 32.2 & 31.3 & 34.9 \\
ADF & 17.7 & 19.3 & 17.9 & 21.5 \\
Lignin, \% of NDF & 9.9 & 9.5 & 10.2 & 9.3 \\
Starch & 27.5 & 23.0 & 29.9 & 21.0 \\
Sugar & 6.1 & 6.2 & 5.0 & 6.3 \\
Crude fat & 2.7 & 2.8 & 2.9 & 2.8 \\
Neutral detergent insoluble CP, \% of CP & 9.3 & 11.9 & 15.6 & 15.5 \\
Acid detergent insoluble CP, \% of CP & 2.0 & 2.7 & 2.2 & 3.0 \\
\hline
\end{tabular}

reported in cattle fed similar diets with similar milk yields (Wattiaux and Karg, 2004). Milk protein percentage and yield were significantly greater for cattle fed the higher starch diets, consistent with the observation that higher starch yields greater propionate supply, which affects milk protein yield (Raggio et al., 2006).

\section{Rumen $\mathrm{pH}, \mathrm{NH}_{3}-\mathrm{N}, \mathrm{MUN}$, and Plasma Urea $\mathrm{N}$}

Rumen $\mathrm{pH}$ was relatively consistent among all treatments, with dietary means ranging from 5.83 to 6.08 , and no significant effect of dietary $\mathrm{CP}$, starch, or $\mathrm{Ru}-$ mensin (Table 6). Milk urea-N, plasma urea-N (PUN), and ruminal $\mathrm{NH}_{3}-\mathrm{N}$ concentrations were significantly increased by feeding the high-protein diets $(P<0.01$; Tables 5 and 6 ), consistent with previous data on lac- tating dairy cattle fed similar levels of CP (Broderick, 2003; Ipharraguerre and Clark, 2005).

Rumensin significantly decreased rumen $\mathrm{NH}_{3}-\mathrm{N}$ concentrations $(P=0.03)$ among treatments (Figure 1 ; Table 6) and this was consistent with the model described by Russell and Strobel (1989) where in vitro bacterial ammonia production was reduced through a reduction in feed AA degradation. Although not significant, a numerical increase was observed in the PUN of cattle fed Rumensin. This paradoxical effect has been previously observed but the reason is unclear (Duffield et al., 2003; Martineau et al., 2007). Consistent with previous data, the effect might be indicative of a protein sparing effect of Rumensin, decreasing ruminal AA degradation with concomitant increases in postruminal $\mathrm{N}$ digestion in the small intestine, thereby

Table 5. Body weight, BCS, DIM, DMI, N intake, milk and milk composition and component yields and plasma and milk urea nitrogen content of dairy cows supplemented with different dietary CP and starch concentrations, with or without Rumensin (Rum; Elanco Animal Health, Greenfield, IN)

\begin{tabular}{|c|c|c|c|c|c|c|c|c|c|c|c|c|}
\hline \multirow[b]{2}{*}{ Item } & \multicolumn{4}{|c|}{ High protein } & \multicolumn{4}{|c|}{ Low protein } & \multirow[b]{2}{*}{ SEM } & \multicolumn{3}{|c|}{$P$-value } \\
\hline & $\begin{array}{l}\text { High } \\
\text { starch }\end{array}$ & $\begin{array}{c}\text { Low } \\
\text { starch }\end{array}$ & $\begin{array}{l}\text { High } \\
\text { starch }\end{array}$ & $\begin{array}{l}\text { Low } \\
\text { starch }\end{array}$ & $\begin{array}{l}\text { High } \\
\text { starch }\end{array}$ & $\begin{array}{l}\text { Low } \\
\text { starch }\end{array}$ & $\begin{array}{l}\text { High } \\
\text { starch }\end{array}$ & $\begin{array}{l}\text { Low } \\
\text { starch }\end{array}$ & & Protein & Starch & Rum \\
\hline No. of cows & 3 & 3 & 3 & 3 & 3 & 3 & 3 & 2 & & & & \\
\hline $\mathrm{BW}, \mathrm{kg}$ & 637 & 646 & 688 & 676 & 670 & 665 & 607 & 584 & 37.3 & 0.40 & 0.47 & 0.66 \\
\hline DMI, $\mathrm{kg} / \mathrm{d}$ & 26.8 & 26.1 & 24.3 & 24.9 & 23.2 & 22.7 & 22.6 & 22.1 & 1.47 & $<0.001$ & 0.72 & 0.06 \\
\hline $\mathrm{N}$ intake, $\mathrm{g}$ of $\mathrm{N} / \mathrm{d}$ & 736 & 691 & 644 & 667 & 556 & 542 & 545 & 562 & 43 & $<0.001$ & 0.84 & 0.14 \\
\hline $\mathrm{CP}$ of diet, $\%$ of $\mathrm{DM}$ & 17.1 & 16.5 & 16.4 & 16.6 & 15.0 & 14.9 & 15.1 & 15.6 & 0.30 & $<0.001$ & 0.87 & 0.61 \\
\hline Milk yield, kg/d & 31.2 & 31.5 & 29.3 & 30.3 & 31.7 & 27 & 28.1 & 26.9 & 1.21 & $<0.05$ & $<0.05$ & $<0.1$ \\
\hline Milk fat, $\%$ & 3.97 & 4.01 & 3.86 & 3.79 & 3.74 & 3.58 & 3.71 & 3.83 & 0.35 & 0.57 & 0.96 & 0.95 \\
\hline Milk fat yield, $\mathrm{kg} / \mathrm{d}$ & 1.71 & 1.74 & 1.54 & 1.57 & 1.62 & 1.31 & 1.43 & 1.40 & 0.16 & 0.19 & 0.24 & 0.47 \\
\hline Milk protein, $\%$ & 2.97 & 2.98 & 2.73 & 2.66 & 2.73 & 2.60 & 2.84 & 2.80 & 0.16 & 0.55 & $<0.01$ & 0.70 \\
\hline Milk urea $\mathrm{N}, \mathrm{mg} / \mathrm{dL}$ & 10.84 & 9.30 & 11.75 & 10.94 & 8.43 & 8.95 & 6.94 & 8.01 & 0.75 & $<0.01$ & 0.34 & 0.98 \\
\hline Plasma urea N, mg/dL & 15.26 & 12.49 & 13.47 & 13.28 & 8.17 & 8.75 & 7.67 & 6.83 & 0.97 & $<0.01$ & 0.02 & 0.29 \\
\hline
\end{tabular}


Table 6. Rumen $\mathrm{pH}$, ammonia levels, and fecal and urinary nitrogen excretion for dairy cows supplemented with different dietary CP and starch concentrations, with or without Rumensin (Rum; Elanco Animal Health, Greenfield, IN)

\begin{tabular}{|c|c|c|c|c|c|c|c|c|c|c|c|c|}
\hline \multirow{2}{*}{ Item } & \multicolumn{4}{|c|}{ High protein } & \multicolumn{4}{|c|}{ Low protein } & \multirow{2}{*}{ SEM } & \multirow{2}{*}{\multicolumn{3}{|c|}{$P$-value }} \\
\hline & \multicolumn{2}{|c|}{ Rumensin } & \multicolumn{2}{|c|}{ No Rumensin } & \multicolumn{2}{|c|}{ Rumensin } & \multicolumn{2}{|c|}{ No Rumensin } & & & & \\
\hline No. of cows & 3 & 3 & 3 & 3 & 3 & 3 & 3 & 2 & & & & \\
\hline Ruminal $\mathrm{NH}_{3}-\mathrm{N}, \mathrm{mg} / \mathrm{dL}$ & 10.13 & 8.29 & 13.99 & 11.32 & 4.89 & 5.79 & 6.94 & 5.75 & 1.38 & $<0.01$ & 0.16 & 0.03 \\
\hline Fecal N, g/d & 217 & 215 & 202 & 190 & 176 & 179 & 181 & 183 & 13.2 & $<0.01$ & 0.80 & 0.40 \\
\hline Urinary $\mathrm{N}, \mathrm{g} / \mathrm{d}$ & 229 & 183 & 208 & 199 & 175 & 142 & 125 & 153 & 18.8 & $<0.01$ & 0.27 & 0.45 \\
\hline Urine urea $\mathrm{N}, \mathrm{g} / \mathrm{d}$ & 124.0 & 97.1 & 111.8 & 114.1 & 87.1 & 83.0 & 71.9 & 72.6 & 12.8 & $<0.01$ & 0.20 & 0.22 \\
\hline Milk N, g/d & 193 & 203 & 165 & 173 & 180 & 153 & 173 & 155 & 14.3 & 0.16 & 0.22 & 0.36 \\
\hline $\mathrm{N}$ balance, $\mathrm{g} / \mathrm{d}$ & 99 & 97 & 66 & 111 & 32 & 77 & 73 & 71 & 33.0 & 0.24 & 0.38 & 0.87 \\
\hline $\mathrm{N}$ balance, $\%$ & 13.5 & 13.8 & 8.8 & 16.9 & 5.5 & 4.9 & 13.1 & 4.3 & 4.94 & 0.50 & 0.34 & 0.75 \\
\hline Urine N:milk N & 1.18 & 0.91 & 1.26 & 1.25 & 0.98 & 0.96 & 0.73 & 1.05 & 0.162 & 0.12 & 0.95 & 0.63 \\
\hline
\end{tabular}

${ }^{1} \mathrm{MNE}=$ milk nitrogen efficiency (milk N:feed N).

decoupling urea formation from ruminal $\mathrm{NH}_{3}-\mathrm{N}$ concentration (Poos et al., 1979).

Additionally, it is possible that Rumensin was systemically functional in a manner that retained urea-
$\mathrm{N}$ in the blood, potentially by acting on the kidneys or aquaporins throughout the body (Mollajew et al., 2010). However, no consistent effects of Rumensin on urea kinetics were observed in this study, indicating

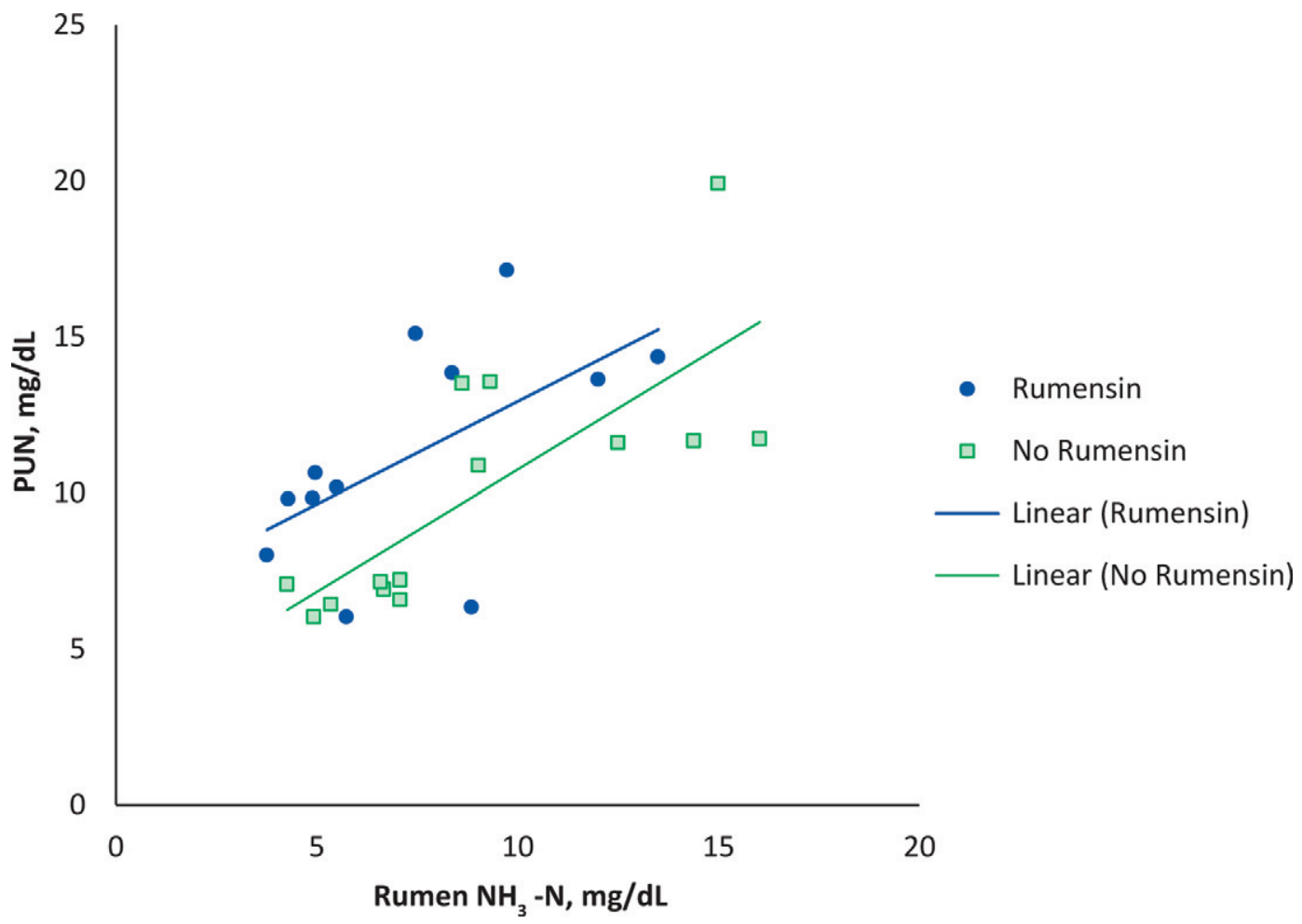

Figure 1. Relationship between plasma urea-N (PUN) and rumen ammonia $\left(\mathrm{NH}_{3}-\mathrm{N}\right)$ for animals consuming diets with $(\bullet)$ or without $(\mathbf{})$ Rumensin (Elanco Animal Health, Greenfield, IN). The equation describing the relationship in cattle fed Rumensin is $\mathrm{y}=0.658 \mathrm{x}+6.3574$, $\mathrm{R}^{2}$ $=0.34$; the equation describing the relationship between PUN $(\mathrm{mg} / \mathrm{dL})$ and rumen $\mathrm{NH}_{3}-\mathrm{N}(\mathrm{mg} / \mathrm{dL})$ without Rumensin is $\mathrm{y}=0.7833 \mathrm{x}+2.9214$, $\mathrm{r}=0.77$. Color version available in the online PDF. 
that this either was not a possibility or that certain regulatory factors counteracted each other to result in similar urea fluxes among treatments.

\section{Nitrogen Excretion}

Among all diets, $\mathrm{N}$ intake was $129 \mathrm{~g}$ of $\mathrm{N} / \mathrm{d}$ higher for the high CP diets, of which $59 \%$ was excreted in the manure (40\% via urine and $19 \%$ via feces) and $11 \%$ in milk. Because these are the treatment mean averages for high versus low protein, they are relative in scale rather than descriptive of total $\mathrm{N}$ balance. The means are comparable to a series of trials feeding cows 8 to $12 \% \mathrm{MP}$ (as \% of DM), in which $83 \%$ of the increased MP was excreted in manure (61\% via urine and $22 \%$ via feces) and $17 \%$ in milk (Weiss et al., 2009b). Feeding the high-protein diets resulted in an average of 82 $\mathrm{g}$ of $\mathrm{N} / \mathrm{d}$ more manure $\mathrm{N}$ excretion (Table 6), primarily in the urine. Consistent with previous studies, excess $\mathrm{N}$ intake beyond that required for milk and growth was excreted in the manure and primarily through increased urinary $\mathrm{N}$ excretion, and differences in urinary $\mathrm{N}$ excretion were greater than those for fecal $\mathrm{N}$ excretion (Weiss et al., 2009b). Fecal $\mathrm{N}$ excretion was not significantly affected by dietary starch (Table 6).

Increases in urinary $\mathrm{N}$ excretion and PUN concentration with Rumensin feeding have been observed in previous studies (Poos et al., 1979; Martineau et al., 2007). Because Rumensin generally increased PUN concentrations in this study, we would expect to see correspondingly higher urinary $\mathrm{N}$ excretion; however, we found an inconsistent relationship between the 2 measurements, with Rumensin increasing urinary $\mathrm{N}$ excretion on the high-starch diets but having a negligible effect in low-starch diets (Table 6, interaction of starch and Rumensin, $P=0.04$ ). This effect may be related in part to PUN concentrations but might also be a function of fecal and urine urea- $\mathrm{N}$ excretion, as increases in PUN did not consistently result in increased urinary urea excretion. What is clear from these results is that Rumensin facilitates a shift of ammonia out of the rumen and into the plasma, directly or indirectly, leading to higher observed PUN but not positively affecting urinary $\mathrm{N}$ excretion. Rumensin might also be affecting the animal systemically, but these results should be replicated with more animals in a focused study. Increases in fecal $\mathrm{N}$ with Rumensin also occurred in the high-protein diets, which might be a function of higher $\mathrm{N}$ intakes in those diets rather than a shift in $\mathrm{N}$ flows to the hindgut versus the rumen. Although Rumensin diets had numerically higher $\mathrm{N}$ excretion, approximately $21 \mathrm{~g}$ of N/d among all treatments, it also increased milk yield by $1.8 \mathrm{~kg} / \mathrm{d}$, resulting in no significant change in either urine N:milk $\mathrm{N}$ or manure N:milk $\mathrm{N}$ ratios (Table
6 ). The Rumensin-supplemented diets had numerically lower urine $\mathrm{N}$ :milk $\mathrm{N}$ ratios in the high-protein diets and relatively unchanged ratios in the low-protein diets.

\section{Urea Kinetics}

Urea-N entry rate (UER) was $25 \%$ higher $(P=$ 0.02 ) and gastrointestinal tract (GIT) urea entry rate (GER) tended to be higher $(P=0.07)$ in cattle fed the high-protein diets (Table 7). Urea entry rate averaged approximately $57 \%$ of total $\mathrm{N}$ intake for cattle with and without Rumensin, and GER was similar at 43 and $42 \%$ of $\mathrm{N}$ intake for cattle fed and not fed Rumensin, respectively. These values were very similar to the average values described by Lapierre and Lobley (2001), where $58 \%$ of $\mathrm{N}$ intake was converted to urea and approximately $38 \%$ of $\mathrm{N}$ intake recycled to the GIT.

Various studies have demonstrated both urea synthesis and urea- $\mathrm{N}$ recycling to correspond to dietary $\mathrm{N}$ intake (Valkeners et al., 2007; Martineau et al., 2011). In this study, $\mathrm{N}$ intake was correlated with UER ( $\mathrm{r}=$ $0.81)$ and GER $(r=0.78)$ and therefore the relationship between $\mathrm{N}$ intake and urea entry and partition was consistent with previous observations. Neither dietary starch nor Rumensin significantly affected any urea-N kinetic measurements (Table 7). This was unanticipated, because Rumensin-fed cattle were observed to have lower ruminal $\mathrm{NH}_{3}-\mathrm{N}$ concentrations, which should have resulted in lower UER and increased ruminal urea-N entry along with greater PUN concentrations, which would presumably stimulate urea- $\mathrm{N}$ excretion and increase ruminal urea-N entry (Sunny et al., 2007). Lower ruminal $\mathrm{NH}_{3}-\mathrm{N}$ concentrations have been observed to increase urea- $\mathrm{N}$ entry to the rumen (Marini and Van Amburgh, 2003), but it is also likely that the concentration gradient responsible for such $\mathrm{N}$ movement is most influential in the rumen epithelium rather than in the rumen fluid per se (Kristensen et al., 2010). Plasma urea concentration has also been observed to affect urea-N entry, as urea infusions lead to higher GER values (Sunny et al., 2007; Kristensen et al., 2010). It was our hypothesis that the ability of Rumensin to reduce rumen ammonia concentration would stimulate urea-N entry into the rumen or GIT, or both. However, this did not occur in this study, as none of Rumensin's effects on urea- $\mathrm{N}$ kinetics approached significance.

Based on the hypothesis and experimental design, a stimulatory effect of dietary starch on GER was anticipated, as previous studies have demonstrated increases in GER resulting from higher NFC fermentation (Kennedy, 1980; Gozho et al., 2008). Both UER and GER were numerically increased by high dietary starch in the high-protein diets, but were numerically decreased in the low-protein diets. Rapid starch fermentation or 
Table 7. Urea-nitrogen recycling kinetics for lactating dairy cows supplemented with high or low dietary CP levels with or without Rumensin (Rum; Elanco Animal Health, Greenfield, IN) and high or low starch concentrations

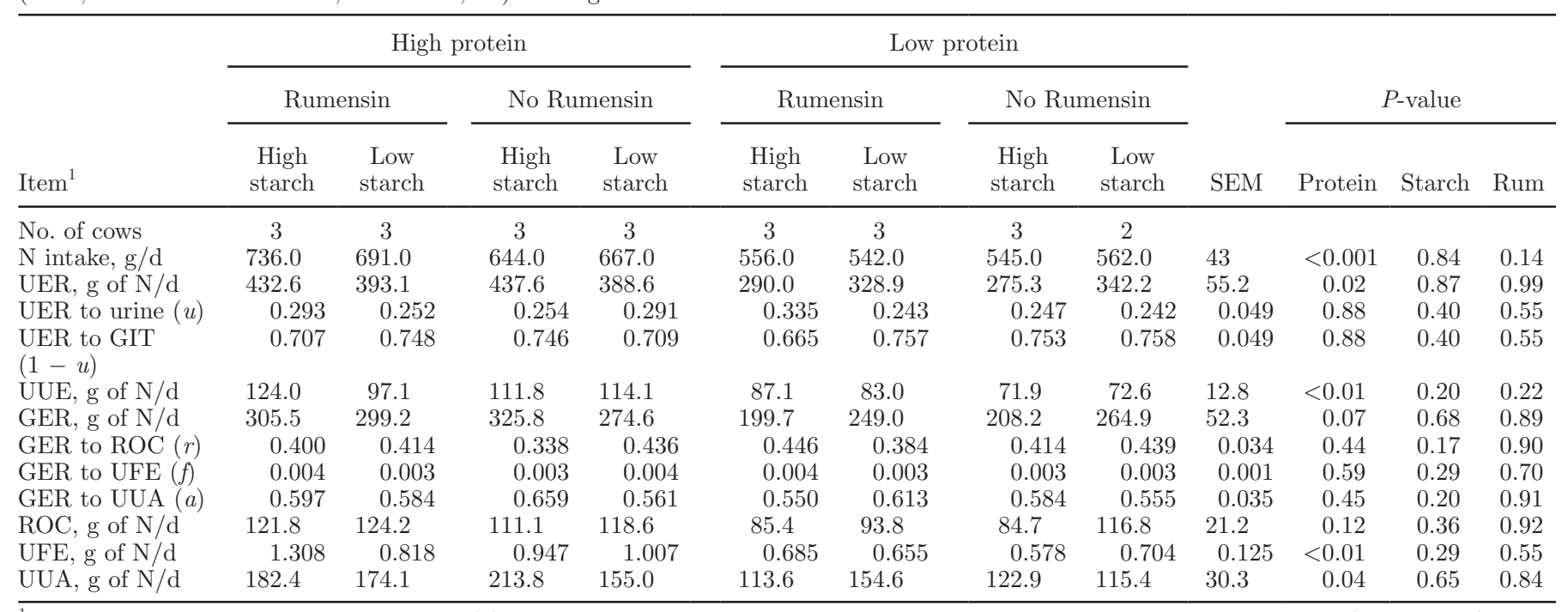

${ }^{1}$ UER $=$ urea-N entry rate; UER to urine $(u)=$ the proportion of UER that enters the urine; UER to gastrointestinal tract $($ GIT; $1-u)=$ the proportion of UER that enters the GIT; UUE = urinary urea elimination rate; GER = GIT urea entry rate, or recycled urea-N; GER to ROC $(r)=$ the proportion of GER that re-enters the ornithine cycle; GER to UFE $(f)=$ the proportion of GER that exits the animal in the feces; GER to UUA $(a)=$ the proportion of GER that is utilized for anabolism; ROC = urea returning to the ornithine cycle; UFE $=$ urea-N excreted in the feces; and UUA = urea-N utilized for anabolic purposes.

poor microbial capture of fermented energy might have led to the higher ruminal $\mathrm{NH}_{3}-\mathrm{N}$ concentrations and UER measurements observed with high dietary starch in the high-protein diets. However, the high-starch treatment did not affect the distribution of urea, as the partitioning of UER to the urine $(u)$ or GIT $(1-u)$ were not affected, which might indicate that the starch was not fermented sufficiently in the rumen to stimulate urea entry into the rumen. It was expected that dietary starch, especially in the form of steam-flaked corn, would stimulate urea-N entry to the rumen via its effects on urea permeability of the rumen epithelium. Both VFA production and an increase in $\mathrm{N}$ gradient due to microbial capture of $\mathrm{NH}_{3}-\mathrm{N}$ would be expected to increase ruminal urea-N entry (Kennedy et al., 1981; Abdoun et al., 2006). Cattle fed the high-starch diets did demonstrate a trend to increase the use of recycled urea- $\mathrm{N}$ for anabolism instead of returning to the ornithine cycle for all diets except low-protein diets with Rumensin (Table 7). This suggests that dietary starch was able to stimulate microbial capture of some urea$\mathrm{N}$ re-entering the rumen or potentially the hindgut if fermented postruminally. However, the effect of dietary starch on the total amount of urea- $\mathrm{N}$ for anabolism was not significant.

We observed a significant dietary starch and $\mathrm{Ru}-$ mensin interaction $(P=0.01)$, which resulted in Rumensin lowering the proportion of GER utilized for anabolism $(a)$ in cattle fed high-starch diets but increasing it on low-starch diets (Table 7). Rumensin also increased the proportion of GER exiting in the feces in cattle fed high-starch diets, but decreased it in those fed low-starch diets (Rumensin and starch interaction, $P=0.01$ ). Corresponding changes were observed in the proportion of GER returning to the ornithine cycle $(r)$, as $r+a+f=1$, where $f$ is the proportion of GER that exits the animal in the feces. Our hypothesis was that Rumensin would improve anabolic utilization of recycled urea- $\mathrm{N}$ by reducing ruminal deamination of feed protein and providing more opportunity for urea re-entering the rumen to be converted to microbial protein. Even though Rumensin decreased ruminal $\mathrm{NH}_{3}-\mathrm{N}$ concentrations, this did not consistently translate into more utilization of urea-N as would be expected from the competitive standpoint of similar amounts of GER with lower ruminal $\mathrm{NH}_{3}-$ $\mathrm{N}$ concentrations. Rumensin might have affected the proportion of urea entering the hindgut, either by affecting urea transport systemically or simply through its effects on PUN concentration. The cattle fed the high-starch diets with Rumensin had increased PUN concentrations and might also have had proportionally higher hindgut urea entry and therefore lower anabolic utilization of urea. The proportion of GER that exited in the feces did increase when Rumensin was present in the high-starch diets (Rumensin and starch interaction, $P=0.01)$. As neither PUN nor ruminal $\mathrm{NH}_{3}-\mathrm{N}$ concentrations changed in parallel to these shifts in GER to the feces or for anabolism, it is difficult to determine the cause of these shifts. 
Table 8. Correlation coefficients between various urea-N kinetic measurements in dairy cows by either level or dietary starch, Rumensin (Elanco Animal Health, Greenfield, IN), or among all treatments

\begin{tabular}{|c|c|c|c|c|c|}
\hline \multirow[b]{2}{*}{ Parameter $^{1}$} & \multicolumn{5}{|c|}{ Correlation coefficient } \\
\hline & High starch & Low starch & No Rumensin & Rumensin & All treatments \\
\hline UER: $u$ & -0.27 & -0.52 & -0.18 & $-0.65^{*}$ & $-0.37^{*}$ \\
\hline UER:GER & $0.98^{* *}$ & $0.94^{* *}$ & $0.96^{* *}$ & $0.97^{* *}$ & $0.97^{* *}$ \\
\hline GER: $a$ & $0.62^{*}$ & 0.18 & 0.42 & 0.43 & $0.43^{*}$ \\
\hline GER:UUA & $0.99^{* *}$ & $0.93^{* *}$ & $0.97^{* *}$ & $0.97^{* *}$ & $0.97 * *$ \\
\hline GER: $r$ & $-0.62^{*}$ & -0.18 & -0.43 & -0.42 & $-0.43^{*}$ \\
\hline GER:ROC & $0.95^{* *}$ & $0.84^{* *}$ & $0.87^{* *}$ & $0.90^{* *}$ & $0.90^{* *}$ \\
\hline
\end{tabular}

The amount of urea-N utilized for anabolism was significantly higher for cattle fed the high-protein diets $(P=0.04)$. Although the partitioning of urea-N entering the GIT was not affected by dietary $\mathrm{CP}(P=0.44$ to 0.59 ), the much larger amounts of $\mathrm{N}$ entering the urea cycle and subsequent release in the GIT led to higher values overall (Table 8). These results suggest that dietary changes might in fact stimulate productive utilization of urea but these shifts in urea kinetics may be overshadowed by larger changes in dietary CP.

Gastrointestinal entry rate was highly correlated to UER among all treatments $(\mathrm{r}=0.97$; Table 8), indicating that dietary treatments did not have a significant effect on $\mathrm{N}$ recycling beyond their effects on urea synthesis. It has been hypothesized that urea-N moves across the rumen epithelium proportionally to the $\mathrm{NH}_{3}$ gradient (Houpt and Houpt, 1968). Previous work has demonstrated an inverse relationship between the amount of urea-N entering the rumen and ruminal $\mathrm{NH}_{3}-\mathrm{N}$ concentrations, suggesting that urea flow is proportional to the $\mathrm{N}$ gradient (Kennedy, 1980). In this study, recycled urea-N (GER) and ruminal $\mathrm{NH}_{3-}$ $\mathrm{N}$ concentrations were weakly correlated $(\mathrm{r}=0.40)$, indicating that higher ruminal $\mathrm{NH}_{3}-\mathrm{N}$ concentrations corresponded to higher urea-N entry rates (Table 8 ). This suggests that $\mathrm{N}$ intake and total $\mathrm{N}$ pool sizes in the rumen and blood might overwhelm the more subtle mechanisms at the GIT epithelial border. This conclusion was supported by higher correlations between GER and PUN concentration $(\mathrm{r}=0.66)$. Other work has also indicated PUN concentration in the short-term or $\mathrm{N}$ intake over the long-term, or both, to be more important determinants of urea entry rate than rumen $\mathrm{NH}_{3}-\mathrm{N}$ concentrations per se (Kristensen et al., 2010; Røjen and Kristensen, 2012). Therefore, PUN appears to be a better predictor of GER than ruminal $\mathrm{NH}_{3}$ $\mathrm{N}$ concentrations, although it is possible that both may have subtle effects on $\mathrm{N}$ entry (Marini and Van
Amburgh, 2003). Higher observed correlations might be due in part to the stability of PUN measurements compared with the measurement of ruminal $\mathrm{NH}_{3}-\mathrm{N}$. An interesting observation in this study was that Rumensin appeared to shift $\mathrm{N}$ from ruminal $\mathrm{NH}_{3}-\mathrm{N}$ to PUN, but this was without concomitant increases in GER. Therefore, these data suggest altered transport of urea within the animal, but an explanation of the effect of Rumensin on urea transporters or kidney function is lacking in the literature.

Furthermore, rumen $\mathrm{pH}$ has been suggested to play a role in urea recycling via its effects on $\mathrm{NH}_{3} / \mathrm{NH}_{4}{ }^{+}$equilibrium and rumen wall solubility (Houpt and Houpt, 1968). In this study, $\mathrm{pH}$ was not correlated with GER among treatments $\left(\mathrm{R}^{2}=0.06\right.$; data not shown). Thus, within the conditions of this experiment, $\mathrm{pH}$ did not affect urea- $\mathrm{N}$ entry at a magnitude large enough to be observed. However, we did not observe a wide range of $\mathrm{pH}$ values and the lack of relationship is not surprising. More recent work has suggested that rumen fluid $\mathrm{pH}$ might not be as significant of a factor in $\mathrm{NH}_{3} / \mathrm{NH}_{4}{ }^{+}$ transport across the rumen epithelium as its effect on local $\mathrm{pH}$ of the apical epithelial wall. This $\mathrm{pH}$ appears to be highly affected by VFA and $\mathrm{CO}_{2}$ concentrations, and thus $\mathrm{N}$ transport is directly affected by $\mathrm{NH}_{3} / \mathrm{NH}_{4}{ }^{+}$ concentrations and by these fermentation by-products (Abdoun et al., 2010).

The total amount of urea synthesized was expected to play a role in affecting its partitioning into the GIT or urine, with larger amounts resulting in less recycling and more excretion via the urine. This was true to some extent in this study, as the proportion of UER that entered the GIT $(u)$ was moderately affected by the amount of UER ( $\mathrm{r}=-0.37$ among treatments; Table 8), with more urea synthesis resulting in a smaller percentage of urea entering the GIT. This relationship was stronger in diets with Rumensin $(\mathrm{r}=-0.65)$ and low starch $(\mathrm{r}=-0.52$; Table 8$)$. However, because of 


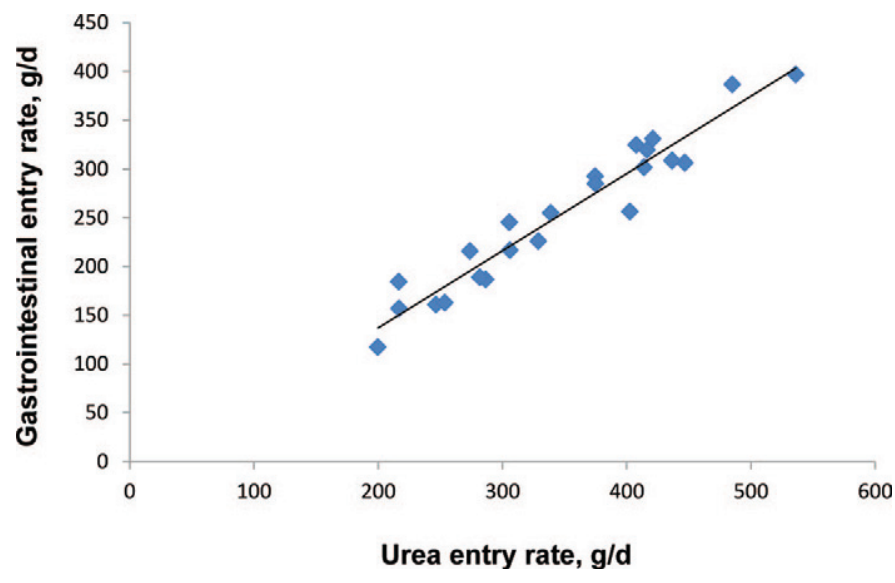

Figure 2. The relationship between urea- $\mathrm{N}$ entry rate and gastrointestinal urea- $\mathrm{N}$ entry rate for each experimental unit across all dietary treatments differing in dietary $\mathrm{CP}$, starch, and Rumensin (Elanco Animal Health, Greenfield, IN) inclusion fed to dairy cattle and continuously infused with ${ }^{15} \mathrm{~N}^{15} \mathrm{~N}$ urea-N. In this experiment, gastrointestinal entry rate $=0.7319 \mathrm{x}-21.27$, where $\mathrm{x}=$ urea entry rate; $\mathrm{r}=0.96$. Color version available in the online PDF.

the relatively small variation in treatment means for $u$ and the lack of treatment effects, the amount of GER was correlated more closely to UER rather than to $u$, suggesting that urea-N recycling to the GIT can be reliably estimated by predicted urea synthesis, with only minor adjustments made by dietary factors. The data in Figure 2 demonstrate the consistency of this relationship by plotting UER and GER by individual experimental unit (each cow appears twice, once for each period).

\section{CONCLUSIONS}

Consistent with previous studies, supplementation with Rumensin resulted in a reduction in rumen $\mathrm{NH}_{3}$ concentration but this reduction did not result in changes in urea production or urea $\mathrm{N}$ recycling and gastrointestinal entry rate. Lactating dairy cattle converted more than $50 \%$ of their $\mathrm{N}$ intake into urea and recycled approximately $73 \%$ of urea synthesized back to the GIT. This appears to be an obligate function to maintain $\mathrm{NH}_{3}$ supply for gastrointestinal bacterial function. Rumensin appeared to have some physiological function beyond the ruminal effect on bacteria because the plasma $\mathrm{N}$ pool was larger without a concomitant shift in either urea-N recycling or urinary excretion.

\section{ACKNOWLEDGMENTS}

We recognize the support of the staff of the dairy (Cornell University, Ithaca, NY) for their help during the experiment. In addition, we thank Gerald Mechor (Elanco Animal Health, Greenfield, IN) for help and suggestions and Andreas Foskolos (Cornell University) for technical support. Further, we thank Elanco Animal Health for financial support of this study and Jay Giesy (Cargill Animal Nutrition) for assistance with diet formulation.

\section{REFERENCES}

Abdoun, K., F. Stumpff, and H. Martens. 2006. Ammonia and urea transport across the rumen epithelium: A review. Anim. Health Res. Rev. 7:43-59.

Abdoun, K., F. Stumpff, I. Rabbani, and H. Martens. 2010. Modulation of urea transport across sheep rumen epithelium in vitro by SCFA and $\mathrm{CO}_{2}$. Am. J. Physiol. Gastrointest. Liver Physiol. 298:G190-G202.

Al-Dehneh, A., J. T. Huber, R. Wanderley, C. B. Theurer, M. Pessarakli, and D. DeYoung. 1997. Incorporation of recycled urea-N into ruminal bacteria flowing to the small intestine of dairy cows fed a high-grain or high-forage diet. Anim. Feed Sci. Technol. $68: 327-338$.

Broderick, G. A. 2003. Effects of varying dietary protein and energy levels on the production of lactating dairy cows. J. Dairy Sci. 86:1370-1381.

Broderick, G. A. 2004. Effect of low level monensin supplementation on the production of dairy cows fed alfalfa silage. J. Dairy Sci. $87: 359-368$.

Chaney, A. L., and E. P. Marbach. 1962. Modified reagents for determination of urea and ammonia. Clin. Chem. 8:130-132.

Choi, C. W., S. Ahvenjarvi, A. Vanhatalo, V. Toivonen, and P. Huhtanen. 2002. Quantification of the flow of soluble non-ammonia nitrogen entering the omasal cannula of dairy cows fed grass silage based diets. Anim. Feed Sci. Technol. 96:203-220.

Colmenero, J. J., and G. A. Broderick. 2006. Effect of dietary crude protein concentration on milk production and nitrogen utilization in lactating dairy cows. J. Dairy Sci. 89:1704-1712.

Duffield, T. F., S. LeBlanc, R. Bagg, K. Leslie, J. Ten Hag, and P. Dick. 2003. Effect of a monensin controlled release capsule on metabolic parameters in transition dairy cows. J. Dairy Sci. 86:1171-1176.

Eschenlauer, S. C., N. McKain, N. D. Walker, N. R. McEwan, C. J. Newbold, and R. J. Wallace. 2002. Ammonia production by ruminal microorganisms and enumeration, isolation, and characterization of bacteria capable of growth on peptides and amino acids from the sheep rumen. Appl. Environ. Microbiol. 68:4925-4931.

Fox, D. G., L. O. Tedeschi, T. P. Tylutki, J. B. Russell, M. E. Van Amburgh, L. Chase, A. N. Pell, and T. R. Overton. 2004. The Cornell Net Carbohydrate and Protein System model for evaluating herd nutrition and nutrient excretion. Anim. Feed Sci. Technol. 112:29-78.

Gozho, G. N., M. R. Hobin, and T. Mutsvangwa. 2008. Interactions between barley grain processing and source of supplemental dietary fat on nitrogen metabolism and urea-nitrogen recycling in dairy cows. J. Dairy Sci. 91:247-259.

Higgs, R. J., L. E. Chase, and M. E. Van Amburgh. 2012. Application and evaluation of the Cornell Net Carbohydrate and Protein System as a tool to improve nitrogen utilization in commercial dairy herds. Prof. Anim. Sci. 29:370-378.

Houpt, T. R., and K. A. Houpt. 1968. Transfer of urea nitrogen across the rumen wall. Am. J. Physiol. 214:1296-1303.

Ipharraguerre, I. R., and J. H. Clark. 2005. Varying protein and starch in the diet of dairy cows. II. Effects on performance and nitrogen utilization for milk production. J. Dairy Sci. 88:2556-2570.

Jonker, J. S., R. A. Kohn, and J. High. 2002. Dairy herd management practices that impact nitrogen utilization efficiency. J. Dairy Sci. 85:1218-1226.

Kennedy, P. M. 1980. The effects of dietary sucrose and the concentration of plasma urea and rumen ammonia on the degradation of urea in the gastrointestinal tract of cattle. Br. J. Nutr. $43: 125-140$.

Kennedy, P. M., R. T. Clarke, and L. P. Milligan. 1981. Influences of dietary sucrose and urea on transfer of endogenous urea to the 
rumen of sheep and numbers of epithelial bacteria. Br. J. Nutr. 46:533-541.

Kennedy, P. M., and L. P. Milligan. 1978. Transfer of urea from the blood to the rumen of sheep. Br. J. Nutr. 40:149-154.

Kristensen, N. B., A. C. Storm, and M. Larsen. 2010. Effect of dietary nitrogen content and intravenous urea infusion on ruminal and portal-drained visceral extraction of arterial urea in lactating Holstein cows. J. Dairy Sci. 93:2670-2683.

Lapierre, H., and G. E. Lobley. 2001. Nitrogen recycling in the ruminant: A review. J. Dairy Sci. 84(E. Suppl.):E223-E236.

Law, R. A., F. J. Young, D. C. Patterson, D. J. Kilpatrick, A. R. G. Wylie, and C. S. Mayne. 2009. Effect of dietary protein content on animal production and blood metabolites of dairy cows during lactation. J. Dairy Sci. 92:1001-1012.

Lobley, G. E., D. M. Bremner, and G. Zuur. 2000. Effects of diet quality on urea fates in sheep as assessed by refined, non-invasive $\left.{ }^{15} \mathrm{~N}^{15} \mathrm{~N}\right]$ urea kinetics. Br. J. Nutr. 84:459-468.

Maltby, S. A., C. K. Reynolds, M. A. Lomax, and D. E. Beever. 2005 Splanchnic metabolism of nitrogenous nutrients and urinary nitrogen excretion in steers fed alfalfa under conditions of increased net absorption of ammonia and L-arginine across the portal-drained viscera. J. Anim. Sci. 83:1075-1087.

Marini, J. C., and M. S. Attene-Ramos. 2006. An improved analytical method for the determination of urea nitrogen isotopomers in biological samples utilizing continuous flow isotope ratio mass spectrometry. Rapid Commun. Mass Spectrom. 20:3736-3740.

Marini, J. C., J. Sands, and M. E. Van Amburgh. 2005. Urea transport systems in relation to recycling. Pages $155-172$ in Ruminant Physiology: Digestion, Metabolism and Impact of Nutrition on Gene Expression, Immunology and Stress. K. Sejrsen, T. Hvelplund, and M. O. Nielsen, ed. Wageningen Academic Publishers, Wageningen, the Netherlands.

Marini, J. C., and M. E. Van Amburgh. 2003. Nitrogen metabolism and recycling in Holstein heifers. J. Anim. Sci. 81:545-552.

Martineau, R., C. Benchaar, H. V. Petit, H. Lapierre, D. R. Ouellet, D. Pellerin, and R. Berthiaume. 2007. Effects of lasalocid or monensin supplementation on digestion, ruminal fermentation, blood metabolites, and milk production of lactating dairy cows. J. Dairy Sci. 90:5714-5725

Martineau, R., D. Sauvant, D. R. Ouellet, C. Cortes, J. Vernet, I Ortigues-Marty, and H. Lapierre. 2011. Relation of net portal flux of nitrogen compounds with dietary characteristics in ruminants: A meta-analysis approach. J. Dairy Sci. 94:2986-3001.

Mollajew, R., F. Zocher, A. Horner, B. Wiesner, E. Klussmann, and P. Pohl. 2010. Routes of epithelial water flow: Aquaporins versus cotransporters. Biophys. J. 99:3647-3656.

Ouellet, D. R., R. Berthiaume, G. E. Lobley, R. Martineau, and H. Lapierre. 2004. Effects of sun-curing, formic acid-treatment or microbial inoculation of timothy on urea metabolism in lactating dairy cows. J. Anim. Feed Sci. 13:323-326.

Poos, M. I., T. L. Hanson, and T. J. Klopfenstein. 1979. Monensin effects on diet digestibility, ruminal protein bypass and microbial protein synthesis. J. Anim. Sci. 48:1516-1524.

Raggio, G., S. Lemosquet, G. E. Lobley, H. Rulquin, and H. Lapierre, 2006. Effect of casein and propionate supply on mammary protein metabolism in lactating dairy cows. J. Dairy Sci. 89:4340-4351.

Recktenwald, E. B. 2007. Effect of feeding corn silage based diets predicted to be deficient in either ruminal nitrogen or metabolizable protein on nitrogen utilization and efficiency of use in lactating cows. MS Thesis. Cornell University, Ithaca, NY.

Rémond, D., J. P. Chaise, E. Delval, and C. Poncet. 1993. Net transfer of urea and ammonia across the ruminal wall of sheep. J. Anim. Sci. $71: 2785-2792$.
Reynolds, C. K., and N. B. Kristensen. 2008. Nitrogen recycling through the gut and the nitrogen economy of ruminants: An asynchronous symbiosis. J. Anim. Sci. 86(E- Suppl.):E293-E305.

Røjen, B. A., and N. B. Kristensen. 2012. Effect of time duration of ruminal urea infusions on ruminal ammonia concentrations and portal-drained visceral extraction of arterial urea- $\mathrm{N}$ in lactating Holstein cows. J. Dairy Sci. 95:1395-1409.

Ruiz, R., G. L. Albrecht, L. O. Tedeschi, G. Jarvis, J. B. Russell, and D. G. Fox. 2001. Effect of monensin on the performance and nitrogen utilization of lactating dairy cows consuming fresh forage. J. Dairy Sci. 84:1717-1727.

Ruiz, R., L. O. Tedeschl, J. C. Marini, D. G. Fox, A. N. Pell, G. Jarvis, and J. B. Russell. 2002. The effect of a ruminal nitrogen (N) deficiency in dairy cows: Evaluation of the Cornell Net Carbohydrate and Protein System ruminal N deficiency adjustment. J. Dairy Sci. 85:2986-2999.

Russell, J. B., and J. L. Rychlik. 2001. Factors that alter rumen microbial ecology. Science 292:1119-1122.

Russell, J. B., and H. J. Strobel. 1989. Effect of ionophores on ruminal fermentation. Appl. Environ. Microbiol. 55:1-6.

Schwab, C. G., P. Huhtanen, C. W. Hunt, and T. Hvelplund. 2005. Nitrogen requirements of cattle. Pages 13-70 in Nitrogen and Phosphorous Nutrition of Cattle, Reducing the Environmental Impact of Cattle Operations. E. Pfeffer and A. Hristov, ed. CABI Publishing, Cambridge, MA.

Sunny, N. E., S. L. Owens, R. L. Baldwin, S. W. El Kadi, R. A. Kohn, and B. J. Bequette. 2007. Salvage of blood urea nitrogen in sheep is highly dependent on plasma urea concentration and the efficiency of capture within the digestive tract. J. Anim. Sci. 85:1006-1013

Sylvester, J. T., S. K. Karnati, B. A. Dehority, M. Morrison, G. L. Smith, N. R. St-Pierre, and J. L. Firkins. 2009. Rumen ciliated protozoa decrease generation time and adjust 18S ribosomal DNA copies to adapt to decreased transfer interval, starvation, and monensin. J. Dairy Sci. 92:256-269.

Thorlacius, S. O., A. Dobson, and A. F. Sellers. 1971. Effect of carbon dioxide on urea diffusion through bovine ruminal epithelium. Am. J. Physiol. 220:162-170.

Tylutki, T. P., D. Fox, V. M. Durbal, L. O. Tedeschi, J. B. Russell, M. Van Amburgh, T. R. Overton, L. Chase, and A. N. Pell. 2008. Cornell Net Carbohydrate and Protein System: A model for precision feeding of dairy cattle. Anim. Feed Sci. Technol. 143:174-202.

Valkeners, D., H. Lapierre, J. C. Marini, and D. Ouellet. 2007. Effect of metabolizable protein supply on nitrogen metabolism and recycling in lactating dairy cows. Pages 417-418 in Proc. 2nd Int. Symp. Energy and Protein, Vichy, France. EAAP publication 124 European Federation of Animal Science (EAAP), Rome, Italy.

Wattiaux, M. A., and K. L. Karg. 2004. Protein level for alfalfa and corn silage-based diets: I. Lactational response and milk urea nitrogen. J. Dairy Sci. 87:3480-3491.

Weiss, W. P., L. B. Willett, N. R. St Pierre, D. C. Borger, T. R. McKelvey, and D. J. Wyatt. 2009b. Varying forage type, metabolizable protein concentration, and carbohydrate source affects manure excretion, manure ammonia, and nitrogen metabolism of dairy cows. J. Dairy Sci. 92:5607-5619.

Wildman, E. E., G. E. Jones, P. E. Wagner, R. L. Boman, H. F Troutt Jr., and T. N. Lesch. 1982. A dairy cow body condition scoring system and its relationship to selected production characteristics. J. Dairy Sci. 65:495-501. 